\title{
The Role of Zoom Cloud Meeting as Learning Online Medium in Pandemic
}

\author{
Dian Rianita $^{1)}$, Indah Muzdalifah ${ }^{2)}$ \\ ${ }_{11,2)}$ Universitas Lancang Kuning \\ email: dianrianita@unilak.ac.id ${ }^{1}$, indah@unilak.ac.id ${ }^{2}$
}

\begin{abstract}
Before the arrival of the Covid 19 virus epidemic, the government actually launched the industry 4.0 and 5.0 revolutions, including in the field of education where the use of technology as a medium or instrument in learning can be maximized to use. However, most of teacher and students were not able to conduct yet. When this epidemic comes, it can't help using technology in the field of education ready or not. The government's policy to execute large-scale social restrictions or PSBB to prevent the transmission of the epidemic has made the implementation of the teaching and learning process online starting from elementary level to university. However, every change certainly causes pros and cons. There are both positive and negative sides to online learning. The positive side can make it easier and more efficient for face-to-face learning to be done from home anytime and anywhere. Meanwhile, the problems that arise include a lack of understanding in the use of technology, inadequate internet network facilities and many more effects as a result of this online learning. Therefore, this article discusses the phenomena that occur around education caused by the impact of the outbreak in the middle of the Covid 19 pandemic.
\end{abstract}

Keywords: Technology, Covid 19, Zoom

\section{Introduction}

At the end of 2019 in December, coronavirus disease or covid 19 has changed the whole aspect around the world. It is called covid which stands for coronavirus disease 19 which means the virus appeared in 2019. This virus originally originated in a city in China which is named Wuhan Hubei Province of China. The entire community in the area is isolated so that it does not spread. But it didn't work. Finally, the virus spread throughout the world, including in Indonesia. WHO set this outbreak as a global pandemic on March 11, 2020.

Precisely in March 2020, this virus had destroyed all aspects of people's lives, especially in Indonesia. Both from the aspects of economic life, socio-culture, religion, and education. The influence of this virus affects every aspect of life. For example, the economy. Due to the implementation of social distance and all activities that must be carried out at home, the community's economy is paralyzed. Largescale social restrictions are inevitable. Many employees were laid off. In terms of religion, worship activities that were previously carried out together in places of worship were eliminated in order to break the chain of the spread of the coronavirus.

Based on the circular of the Minister of Education and Culture Number 36962 / MPK.A / HK / 2020 regarding online learning. Students are forced to leave and study from home. Teachers and guardians are preoccupied with tasks that can replace children studying at home. So that there are various problems that arise with the implementation of the distance learning system.

As for these problems, first, Indonesian people, especially the middle to lower class, are still not familiar with the use of technology. Moreover, not all students have cell phones or smartphone phones which are usually used as tools in online or online learning. This means that there are still many people 
who are still unfamiliar with the use of technology and do not have the tools in online learning. Apart from that, the limited facilities and infrastructure are still far from adequate. For example, students who live in areas that are difficult to reach the internet network have difficulty implementing online learning. In addition, the supporting costs for the tools used in this study. In other words, many housewives have complained about spending on buying internet data packages to communicate and carry out online or online learning.

Another problem arises from the psychological side of children and parents at home. They complained about the difficulty of teaching children at home. Various memes or insinuations from parents complained about their limitations in teaching their children at home. Many children complain about the impatience and anger of their mothers when compared to teachers at school.

In addition, basically, distance learning can never replace face-to-face learning systems in the classroom. However, like it or not, the Indonesian people must be able to adapt to this new system. This happens because not all mothers who become housewives learn psychological and pedagogical science like teachers in schools.

In general, this applies to parents who have children of elementary and junior high school age. Usually, students in SMA have started to be independent in anticipating online learning with their teachers. Even more so for students who are familiar with the use of technology.

There are various applications as a medium for distance learning. Of course, no application is perfect. There are advantages and disadvantages. One application that is booming and is often used is the zoom application. This application allows lecturers and students to interact in a classroom even though it is actually online or online. Therefore this research tries to raise and explore the phenomena and events that arise with the zoom application.

At present, various ways and methods are used by various countries in Asia, including Indonesia, in increasing the learning of English as a foreign language. In this case, for example, it involves combining learning with foreign speakers, analyzing and diagnosing pronunciation through computers and application devices on smartphones, video conferencing with native speakers, and others. In learning a language, direct interaction with native speakers is believed to be an effective method. However, if it is difficult to invite native speakers, using a computer device or an Android-based application through the voice application can help in based verbal messages (Pujiati, 2017).

In Indonesia, foreign language learning has now undergone a very significant revolution. This is evident from the learning process that has changed from conventional learning to E-learning. One method of E-learning is learning that involves computer devices. One computer device that is often used is a smartphone or Android. In mobile learning devices, there are many application designs that are created in an effort to help humans, both as learning media and entertainment or games. Not only an application in learning a foreign language, but it can also be an application specifically designed for people with deaf and mute disabilities (Abdallah \& Fayyoumi, 2016).

The importance of learning English in Indonesia has made various efforts and methods found to improve students' understanding in learning English. The importance of English makes it a prerequisite for several jobs, therefore various ways are carried out in developing and enhancing competencies in this field. In a study in 2017, there were 13 thousand people interviewed. Mastering and being able to speak English is believed to be a guarantee of increasing income up to $61 \%$ depending on the area they work for. (Samuel et al., 2019). The use of smartphones in the learning process has increased by $45.2 \%$ since 2016. This is because applications on smartphones can be used as learning media in education. Even a pronunciation-based android application has begun to be applied in the learning process of foreign languages, especially English in Indonesia (Cavus, 2016).

E-learning or commonly known as Mobile learning is a learning process that is developing in the midst of the current millennial generation. E-Learning is a learning tool that becomes a bridge for the delivery of teaching material from educators to students via the internet or other computer network media. One of the computer devices that can be carried is Android. Android is an operating system for Linux- 
based mobile devices which includes the operating system, middleware, and applications released by Google. Android provides an open platform for developers to create their applications (Harahap \& Putri, 2017).

The basic components in mobile learning consist of students, teachers, learning content, environment and assessment. However, the most important things in the mobile learning process are portability, mobility, connectivity, flexibility, interactivity, context sensitivity, individuality, and accessibility. The advantages of mobile learning, which have a clear camera device, large capacity, wide camera screen, long battery life, and clear sound quality are an attraction for educators, especially English teachers. In addition, the advantage of learning that involves smartphones in learning English is that it can increase motivation which automatically increases students' interest in learning. The use of smartphones in learning English as a foreign language provides a positive side for both students and teachers (Cavus, 2016).

Online learning media is a learning media that is used by utilizing the internet network in its use. This online learning media itself usually uses applications on Android phones or utilizes websites in practice, all use media (Elianur, 2020). E-learning (online learning) includes various applications and processes such as computer-based learning, web-based learning, virtual classrooms, virtual School, virtual Zoom, and other applications. This online learning activity is carried out to replace direct learning activities.

Online learning has several weaknesses, such as the use of the internet network requires adequate infrastructure, requires a lot of money, communication via the internet has various obstacles or slow (Waryanto, 2006)). Even though there are obstacles to online learning, it can be said to be effective if students can achieve learning goals and students are active with the interaction between lecturers and students in learning and not only centering on lecturers. One of the main characteristics of student learning that is very prominent is the ability and willingness in the learning process by directing the learning process according to the needs he wants or also known as self-directed learning or often abbreviated as SDL (Wicaksono, 2012).

As for the advantages of doing online learning, one of them is increasing the level of interaction between students and lecturers/teachers, learning can be done anywhere and at any time (time and place flexibility), reaching students in a broad coverage (potential to reach a global audience), and making it easier to perfect and store learning materials (easy updating of content as well as achievable capabilities) (Waryanto, 2006)). This learning model utilizes technology, especially in helping lecturers and students, especially in managing learning activities (Basori, 2017). With this information technology, it can act as a medium that provides between students and lecturers, learning resources, and means to streamline learning evaluation (Windhiyana, 2020).

Through zoom it is used as online learning, long distances make learning more effective. This is because zoom provides conference videos that can be reached by all participants or students and lecturers. In addition, the video recording is also gated and has a chat feature so that if someone gets a good hearing during the video conference, they can talk via chat. In zoom, you can also schedule the next meeting that will be done. By utilizing this online learning, of course, is a very innovative solution in the midst of the Covid 19 pandemic which requires people to work from home including learning activities in lectures via online (Brahma, 2020).

The disadvantages of zoom are that it lasts 45 minutes in the first session, for the next one you have to sign in again to enter the join meeting in the next session. Another drawback is spending 15-20 minutes in advance to prepare all participants to attend the video conference. With various student constraints such as, unclear audio, visuals, and network connections at the outset prevent early learning using zoom. But after everything is present and ready, the zoom can be effective. Students and lecturers alike rely heavily on the internet for effective use of zoom (Brahma, 2020).

Videos provide a very interesting and direct (live) way of conveying information. Video is the most meaningful medium compared to other media such as graphics, audio and so on. The use of video in 
interactive multimedia will provide new experiences. According to Munir (2012: 289), "Video is a technology of capturing, recording, processing, and storing, transferring, and reconstructing a sequence of still images by presenting scenes in motion electronically". Video provides a rich and lively resource for multimedia applications. Videos are moving images. If the object in the animation is artificial, then the object in the video is real. (Muhibuddin, 2015).

Zoom is a video conferencing service that has practical capabilities in presenting an online meeting atmosphere. As reported by id.cloudhost.com, active Zoom users have increased by around 2.22 million per month since the COVID-19 pandemic broke out globally as of March 2020. This paid application can be accessed free of charge with a maximum user capacity of 100 people and a conference duration limit of around 40 minutes. This application is equipped with the Sharing Screen feature which is able to facilitate the needs of teachers in presenting teaching materials like face-to-face meetings in conventional classrooms to students (Kasmir, 2020).

But on the learner side, researchers found different responses. After being evaluated, the majority of students in the two classes thought that lecturing through Zoom drained their pulse quota. Even so, according to the results of the online conference application comparison test reported by CNBCindonesia.com, it is stated that Zoom has the lowest bandwidth requirement level, which is around $700 \mathrm{Kbps}$. When compared with Skype with $977 \mathrm{Kbps}$, Hangouts with $1100 \mathrm{Kbps}$, and finally WebEx with 1,700 Kbps. In addition to the question of quotas which are considered burdensome, online learning through Zoom sometimes according to some of them is constrained by an unstable signal, so that the Zoom they access is sometimes disconnected. (Cashmere, 2020)

This factor is due to the location coverage of each provider that students use, with different locations where they access Zoom so that this can happen. For this factor, it can be considered as the most crucial aspect, because if lectures through Zoom are still forced, then not all students can benefit from the material presented, because some of them are still constrained by bad signal conditions (Kasmir, 2020).

\section{Methods}

This research is qualitative descriptive research. Qualitative descriptive research is research that explains the phenomena that are happening in society. The research is explained through a description and is supported by some data taken from the test as an indicator of the success or failure of a method, media or approach. In this case, the research uses technology-based learning media which is very helpful and useful in a pandemic situation where face-to-face learning in class is avoided while substantial learning material must be delivered.

\section{Results and Discussion}

The result of this research found that the application of zoom cloud meeting gives a positive impact on online learning systems in the pandemic. Based on the data was collected by a questionnaire from 113 students give respond 78,5\% agree that zoom cloud meeting is as a positive medium in online learning, and 23,36\% disagree. The table below describes the distribution of the questionnaire from 113 students, and then the next table gives the conclusion of the statement:

Table 1. The recapitulation of the questionnaire

\begin{tabular}{clcc}
\hline No. & Year & Agree & Disagree \\
\hline 1 & The use of a new zoom application for me since in the college & $85,8 \%$ & $17,7 \%$ \\
2 & The use of the zoom application is useful for me & $82,3 \%$ & $22,2 \%$ \\
3 & Learning activities through this zoom application add knowledge & $69,1 \%$ & $32,7 \%$ \\
& & \\
to me, especially in English lessons & This zoom application shows the positive side of using distance & $86,7 \%$ & $15,1 \%$
\end{tabular}

Language Learning Innovation in Pandemic Covid-19 Era 
learning

5 The zoom application makes it easier for me to learn English $\quad 78,7 \% \quad 23,9 \%$ using a cellphone even though it is a long-distance

6 Zoom application is the same as learning in class

$67,2 \% \quad 36,3 \%$

7 Zoom application makes it easy to communicate with lecturers

$70 \%$

$30,9 \%$

8 Zoom application makes it easy to communicate with friends

$77,8 \% \quad 22,1 \%$

9 Zoom application makes it easier to communicate than other applications

$71,7 \% \quad 29,2 \%$

10 Lack of zoom only when the internet network is interrupted in my area

Zoom application is the same as learning in class

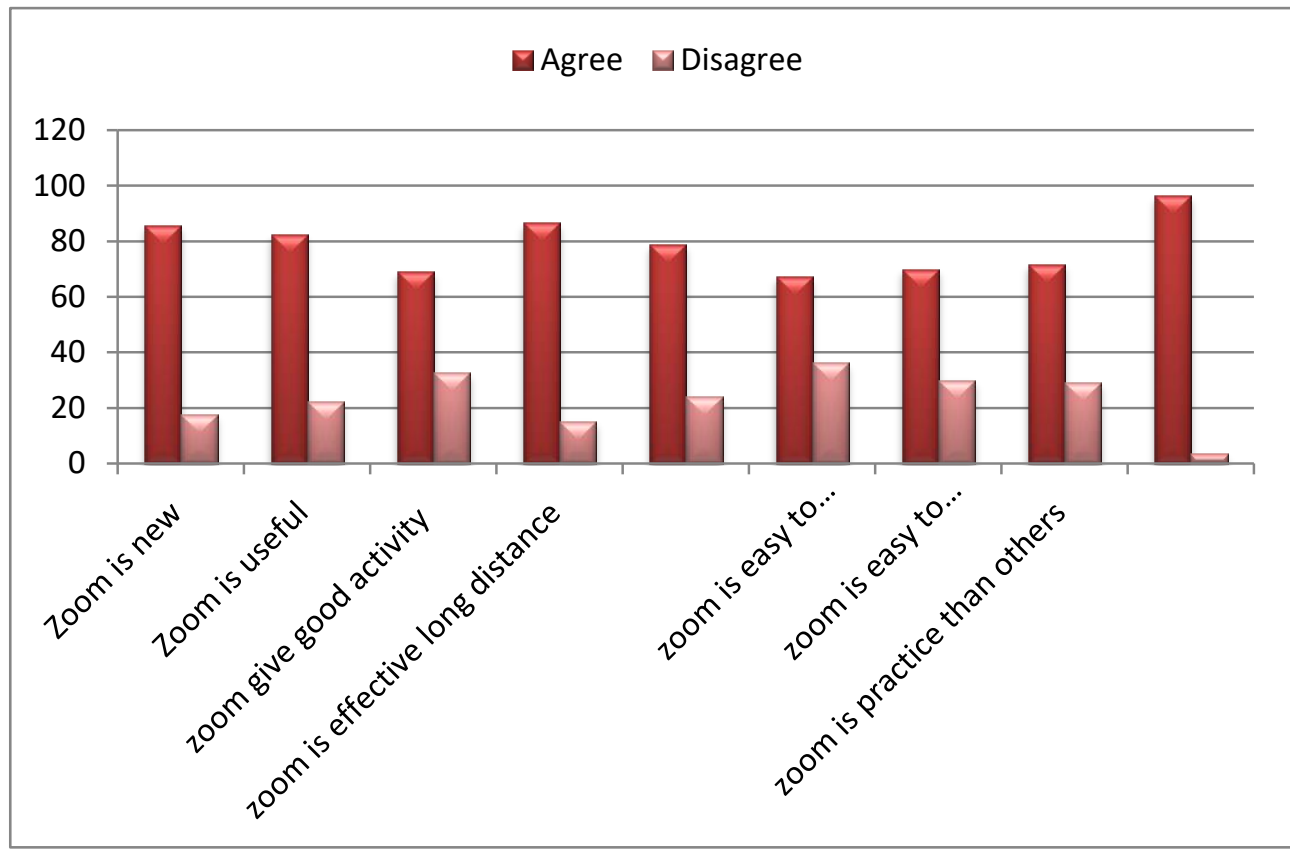

Figure 1. Description of the use zoom cloud meeting

By online questionnaire, from 113 student respondents, it was found that 40 students or $35.4 \%$ stated that they are strongly agreed that the use of the new zoom application since they were in college; 57 people or $50.4 \%$ agreed; 16 people or $14.2 \%$ disagree; and 4 people or $3.5 \%$ disagree.

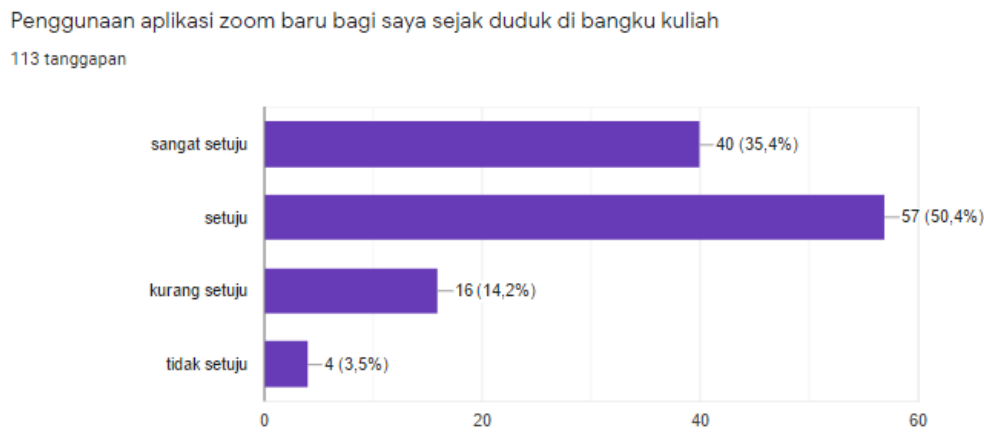


From 113 respondents, 20 people or $17.7 \%$ of students stated that they strongly agreed that using the zoom application was useful; 73 people or $64.6 \%$ agreed, people $20.4 \%$ disagreed; and 2 people or $1.8 \%$ disagreed.

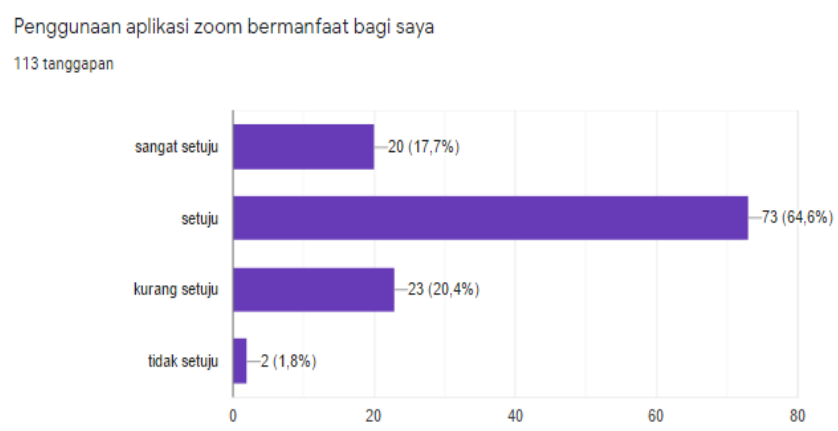

From 113 students 23 person or 20,4\% stated that they are strongly agree about the learning activity through zoom cloud meeting give positive contribution of knowledge especially in English. 55 students or 48 , $7 \%$ stated agree; 32 person or 28, $3 \%$ stated disagree; and 5 person or $4.4 \%$ stated strongly disagree.
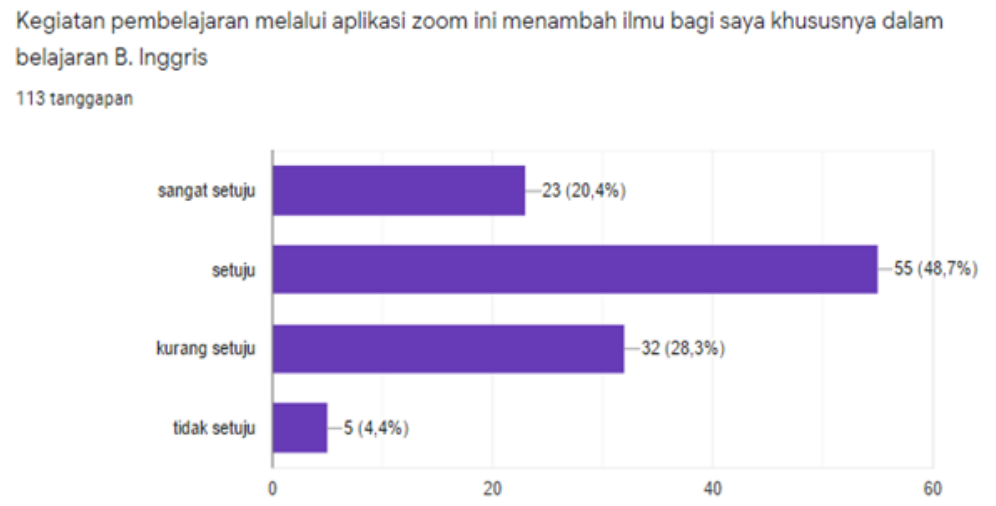

From 113 students 32 person or $28,3 \%$ stated that they are strongly agreed about the application of zoom cloud meeting gives positive impact in long distance learning, 66 person or 58,4\% stated agreed; 16 person or $14,2 \%$ stated disagreed; and 1 person or $0,9 \%$ stated strongly disagreed.

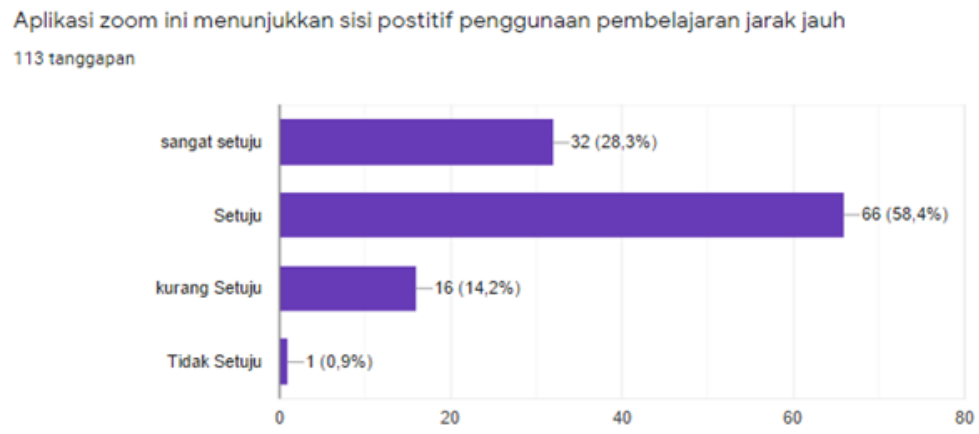

From 113 students 30 person or 26,5\% stated that they are strongly agreed about the use of zoom cloud meeting application makes easy in learning by using cellphone 59 person or $52,2 \%$ stated agreed; 26 person or $23 \%$ stated disagreed; and 1 person or $0,9 \%$ stated strongly disagreed. 
Aplikasi zoom memudahkan saya dalam belajar Bahasa Inggris hanya dengan menggunakan

HP walaupun jarak jauh

113 tanggapan

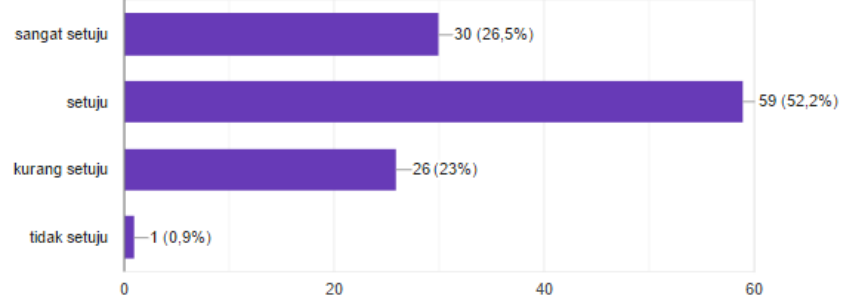

From 113 students 26 person or $23 \%$ stated that they are strongly agreed about the use of zoom cloud meeting application is the same as face-to-face learning in the class, 50 person or 44,2\% stated agreed; 36 person or $31,9 \%$ stated disagreed; and 5 person or $4,4 \%$ stated strongly disagreed.

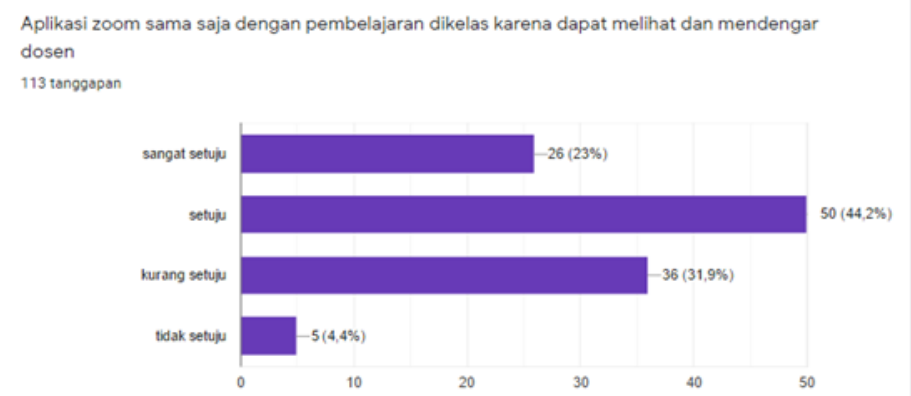

From 113 students 23 person or 20,4\% stated that they are strongly agreed about the use of zoom cloud meeting application makes easy in communicating in the class, 56 person or 49,6\% stated agreed; 30 person or $26,5 \%$ stated disagreed; and 5 person or $4,4 \%$ stated strongly disagreed.

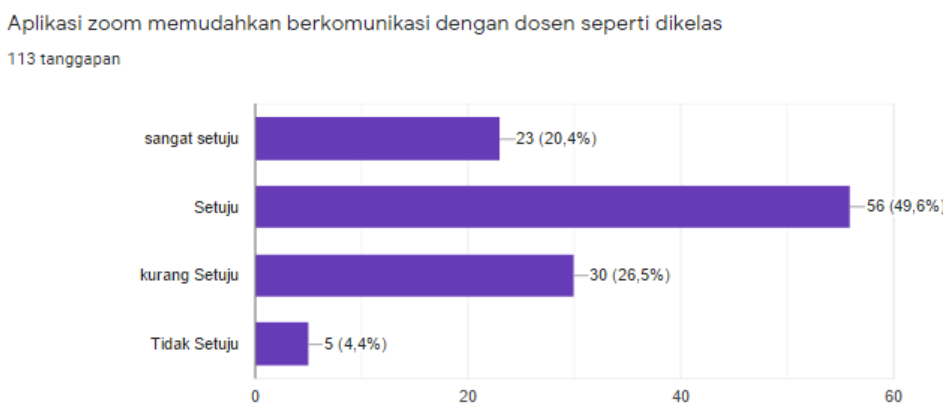

From 113 students 31 person or 27,4\% stated that they are strongly agreed about the use of zoom cloud meeting application makes easy in communicating in the class because it can hear the voice, 57 person or 50,4\% stated agreed; 20 person or $17,7 \%$ stated disagreed; and 5 person or 4,4\% stated strongly disagreed.

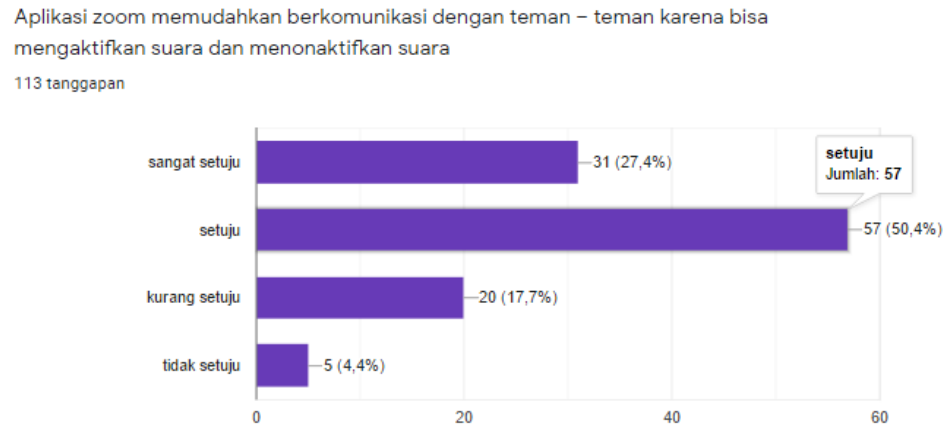


From 113 students 20 person or 17,7\% stated that they are strongly agreed about the use of zoom cloud meeting application is easier in communicating than others application, 61 person or 54\% stated agreed; 29 person or $25,7 \%$ stated disagreed; and 4 person or 3,5\% stated strongly disagreed.

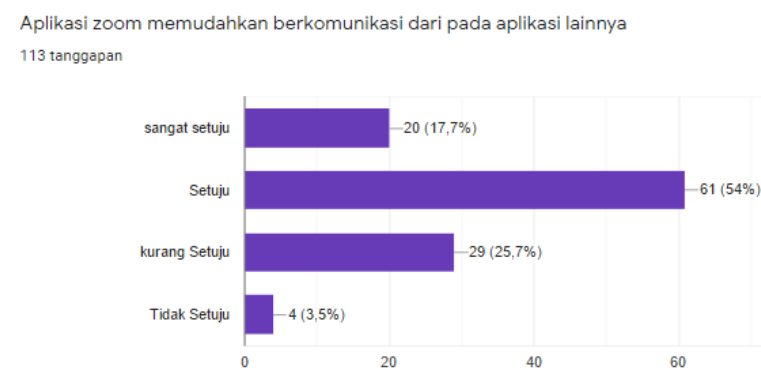

From 113 students 61 people or $54 \%$ stated that they are strongly agreed about the weakness of the zoom cloud meeting application is only when the network of the internet was disturbed, 48 people or $42,5 \%$ stated agreed; 4 people or 3,5\% stated disagreed; nobody stated strongly disagreed.

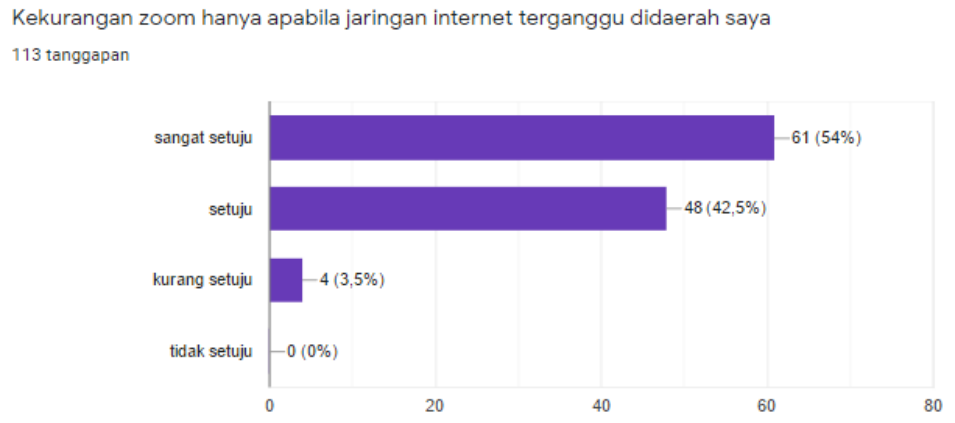

\section{Conclusion}

The purpose of this paper is proving that the use of zoom cloud meeting gives positive contribution online learning in pandemic. Many students agree that the use of zoom cloud meeting application help them in communicate each other. There are two types of online learning, they are synchronous and Asynchronous online learning. Zoom cloud meeting application is one of the types Synchronous online learning which among the students and teacher can communicate each other as they are in the class. Based on the data above it can be concluded that every situation can be used for positive impact. Before a corona virus disease was coming, the government actually launched the industry 4.0 and 5.0 revolutions and asked all the aspect that involved in education aspect to maximize the use of technology. However not every element has been ready yet. Nevertheless, when the pandemic is coming, the use of technology is the choice solving problem in order teaching learning process is running well.

Actually, there are many choices online learning application that can be implemented in the online class. It depends on the teacher creativity to make fun her students in learning even online. As far as we can analyze that zoom cloud meeting is the best way of communicating during teaching learning process especially in English class. Even though, of course every application has the advantages and the weaknesses. The advantages of using the zoom cloud meeting application are the communication between teacher and students or among the students is same as face-to-face communication in the class. The teacher can click silent voice when the sounds of students too crowded. The teacher is also sharing her content of material in learning as they share in focus in the class. Besides, the students are also making 
presentation in zoom cloud meeting and function as host or co-host to share their material in the screen. It is so easy and fun learning.

\section{References}

Abdallah, E. E., \& Fayyoumi, E. (2016). Assistive technology for deaf people based on android platform. Procedia - Procedia Computer Science, 94, 295-301.

Brahma, I. A. (2020). Penggunaan Zoom Sebagai Pembelajaran Berbasis Online Dalam Mata Kuliah Sosiologi dan Antropologi Pada Mahasiswa PPKN di STKIP Kusumanegara Jakarta. Jurnal Pendidikan Nonformal Aksara, 06(02), 97-102.

Cavus, N. (2016). Development of an intellegent mobile application for teaching English pronunciation. Procedia - Procedia Computer Science, 102, 365-369.

Elianur, C. (2020). Pilihan media pembelajaran daring oleh guru PAI di Bengkulu Tengah. Jurnal AsSalam, 4(1), 37-45.

Harahap, N. S., \& Putri, F. A. (2017). Rancang bangun aplikasi pembelajaran bahasa Inggris pada platform android (studi kasus: Sekolah Menangah Atas ). Jurnal CoreIT, 3(1), 41-46.

Kasmir, N. M. (2020). Implementasi Zoom, Google Classroom, dan Whatsapp Group dalam mendukung pembelajaran daring (online) pada mata kuliah Bahasa Inggris lanjut. Jurnal Aksara Public, 4(2), $155-165$.

Muhibuddin, F. (2015). Pengembangan media pembelajaran berbasis video kelas IV SD. Jurnal Dimensi Pendidikan Dan Pembelajara, 3(1), 24-29.

Pujiati, T. (2017). Pemanfaatan Google Translate dalam penerjemahan teks bahasa Inggris ke dalam Bahasa Indonesia. Prosiding Seminar Nasional, 127-136.

Samuel, D., Dias, M., Parente, R. S., Levy, V., Sanches, E., Almeida, J. De, Júnior, B., \& Reis, M. H. (2019). Application focused on english language teaching for children, with speech recognition and synthesizing capabilities. Internatioal Journal of Advanced Engineering Research and Science ( IJAERS), 6495(3), 20-24.

Windhiyana, E. (2020). Dampak Covid-19 terhadap kegiatan pembelajaran online di Perguruan Tinggi Kristen Di Indonesia. Perspektif Ilmu Pendidikan, 34(1), 1-8. 